\title{
A Review on Phytochemicals and Pharmacological Activities as Ethnomedicinal Uses of Duku (Lansium domesticum Corr.)
}

\author{
Muhammad Fauzan Lubis ${ }^{1 *(D)}$, Poppy Anjelisa Hasibuan² ${ }^{2}$, Hafid Syahputra ${ }^{3}$, Ririn Astyka \\ ${ }^{1}$ Department of Pharmaceutical Biology, Faculty of Pharmacy, Universitas Sumatera Utara, Medan, Sumatera Utara, Indonesia; \\ ${ }^{2}$ Department of Pharmacology, Faculty of Pharmacy, Universitas Sumatera Utara, Medan, Sumatera Utara, Indonesia; \\ ${ }^{3}$ Department of Pharmaceutical Chemistry, Faculty of Pharmacy, Universitas Sumatera Utara, Medan, Sumatera Utara, \\ Indonesia; ${ }^{4}$ Bachelor Program, Faculty of Pharmacy, Universitas Sumatera Utara, Medan, Sumatera Utara, Indonesia
}

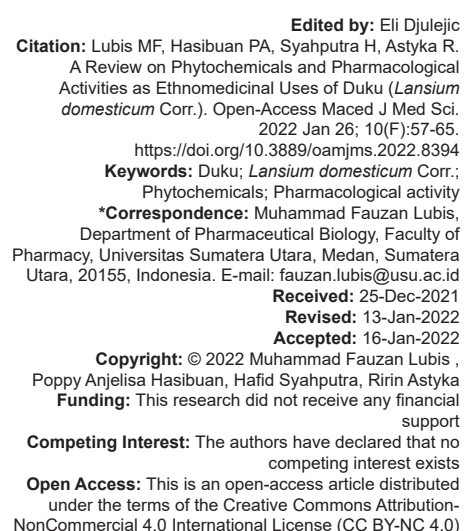
competing interest exist

\section{Abstract}

BACKGROUND: Lansium domesticum Corr. is a plant that is easily found in Indonesia. People use the fruit to be sold because it has a good taste. Some people use other parts of the plant as medicine. This plant has great potentia to be developed as a standardized traditional medicine.

AIM: This article review aims to collect information on secondary metabolite compounds from $L$. domesticum Corr. and its pharmacological activities as antioxidants, antibacterials, and cytotoxics.

METHODS: Data on L. domesticum Corr. or duku were sought and collected for this miniature estimate and perspective. We use the major search engines with specific keywords such as L. domesticum Corr.; duku; morphology; pharmacological effects; secondary metabolites; in vitro; and in vivo.

RESULTS: This review shows that $L$. domesticum Corr. have antioxidant, antibacterial, and cytotoxic activity of various compounds based on the test method used.

CONCLUSIONS: Some parts of L. domesticum Corr. such as leaves, fruit, fruit skins, and seeds contain secondary metabolite compounds. The most common type of active compound is the steroid/terpenoid group. These compounds are responsible for their pharmacological activities such as antioxidants, antibacterials, and cytotoxics.

\section{Introduction}

The Indonesian country is made up of ethnic groups from all over the world. A country with a wide range of medications traditional Indonesian ingredients, including medicinal herbs, is used to make this traditional dish [1], [2]. There are around 30,000 kinds of plants in Indonesia, with 7000 of them having medicinal characteristics. Indonesia's biodiversity is thought to be second only to Brazil's [3]. This makes Indonesia a country with great potential to develop traditional medicines and natural products in medicine. Herbal medicine has been widely recognized in both the developing and developed countries across the world [4]. The use of medicinal plants in medicine is growing due to a variety of materials for medicinal plants, a greater risk-to-use ratio profit, and the weakness of synthetic chemical medications [5].

Lansium domesticum known as duku in Indonesia is a fruit-producing plant that can be found in tropical countries, especially in Indonesia [6]. Duku has a number of societal advantages. In addition to the fruit's great nutritional content, the community believes that duku offers medicinal properties for ailments such as malaria, dysentery, and diarrhea [7]. Duku has been empirically believed that society has many benefits. This plant's advantages may be felt in a variety of disciplines, including agriculture, chemistry, and health. The effectiveness of duku has been reported in several investigations due to the presence of secondary metabolites [8]. However, it is vital to be aware of the scientific facts pertaining to the activity and biological potential of duku. As a consequence, this is the first study to look at the pharmacological action of duku based on the research findings.

\section{Method}

Data on L. domesticum Corr. or duku were sought and collected for this miniature estimate and 
perspective. We use the major search engines, namely, Google Scholar, PubMed, Science Direct, and SciFinder. The search keywords used were from $L$. domesticum Corr.; duku; morphology; pharmacological effects; secondary metabolites; in vitro; and in vivo. The authors rate, discuss, and discuss selected articles. This perspective reflects the author's opinion about the pharmacological activity of $L$. domesticum Corr.

\section{Morphological characteristics}

This plant, also known as duku (L. domesticum Corr.), is a SoutheastAsian native and one of Indonesia's seasonal favorite fruits. The plant is a tropical fruit that is both commercially useful and nutritious. It grows natively in Sumatra, Kalimantan, Sulawesi, and Java in Indonesia [9]. Duku is grown and farmed in various areas of those regions. Because it grows in several countries, duku has many synonyms (Table 1).

Table 1: Synonym for duku in various regions [10]

\begin{tabular}{ll}
\hline Region & Synonym \\
\hline Indonesian & Duku, luku, kokosan, and langsat \\
Burmese & Duku and langsak \\
English & Langsat and duku \\
Philippines & Lanzone, lanzon, lansones, and lanson \\
Malaysia & Langseh and langsep \\
Thailand & Duku, longkong, and langsat \\
Vietnamese & Bonbon \\
\hline
\end{tabular}

Duku is a Meliaceae plant that grows as a tall tree that is erect and persistent. The tree may grow up to $20 \mathrm{~m}$ tall, with a trunk diameter of $35-40 \mathrm{~cm}$. The trunk has deep grooves and sticks out above the ground. The bark is broken, white sticky, and brown-greenish or gray. The skin on the stem is thin and tough to remove [11]. Duku leaves are unusual compound leaves that are placed in a zigzag pattern. Each leaflet is composed of 5-7 long elliptical, flat-edged, asymmetrical base, and tapering ends leaflets. Duku leaves are dark green or slightly yellowish on both sides. Compound interest is a type of interest that comes in bunches. The flowers have a bowl-like shape and are known as sissy flowers (there are pistils and stamens in one flower). The flower petals are five strands thick and thick. The floral crown is thick and made up of $4-5$ strands. There will be $4-5$ chambers in the fruit [12].

The fruit comes in bunches, with a round or circular shape that is around $2-4 \mathrm{~cm}$ in diameter. The juvenile duku fruit has a green skin that becomes yellow as it ripens. Flesh is thick, white, clear, and somewhat translucent, with a chewy texture and a sweet or sweet acidity flavor [13]. When ripe duku fruit is opened, it does not emit sap, the seeds are small and few, the flesh is thick and copious, and the flesh has a pleasant taste [14]. Duku plants require around $2000-3000 \mathrm{~mm}$ of annual rainfall, a temperature of $25-25^{\circ} \mathrm{C}$, and a 3-4 week dry season to boost bloom growth. Duku grows at a height of $<600 \mathrm{~m}$, with a clay soil type, a $\mathrm{pH}$ of 5.5-6.6, and adequate drainage [15], [16].

\section{Natural product identification of L. domesticum Corr.}

Natural products are secondary metabolites that come from plants or animals. Natural products are pharmacological and biologically active chemical compounds found in nature [17]. Natural products are commonly employed in medication development and discovery. Many of the plant's secondary metabolites have noteworthy pharmacological properties [18]. Not many secondary metabolites have been identified from this plant (Table 2). Hence, it requires a more intimate touch to obtain data about these compounds. This is necessary for drug development.

Secondary metabolites are non-nutritive compounds that play a crucial function in an organism's survival in the environment [19]. Plants are known to contain a wider range of secondary metabolites than animals and microbes. The majority of secondary metabolites can be employed as a pharmaceutical component [20]. Tannins, flavonoids, alkaloids, steroids/terpenoids, phenols, and other chemical substances found in plants can be employed as therapeutic medicines [21], [22], [23]. The components of these bioactive chemicals are largely produced from secondary metabolites and are pharmacological [24].

In L. domesticum Corr., many researchers have attempted to identify active metabolite compounds. It was reported that these plant materials such as leaves, fruit, fruit peel, and seeds are rich in active metabolite compounds (Table 2). Some of them are new compounds and this will be very useful for drug development [25]. Secondary metabolites, when taken as a single component or in combination, can be effective and safe even when synthetic medications fail [26]. They may potentially enhance or synergize the effects of other pharmaceutical ingredients [27] for further discussion will be discussed the relationship of secondary metabolites and their pharmacological activity in L. domesticum Corr.

\section{Pharmacological activity of $L$. domesticum}

Corr.

Duku (L. domesticum Corr.) is an unusual and potentially valuable tropical fruit from the Meliaceae (Mahogany) family, however, it is not yet widely planted [39]. The majority of the fruits sold in marketplaces come from trees in community plantations. This plant has been grown for a long time, and it was first noted by Ma Huan, a Chinese traveler, in the year 1413 [40]. This tropical plant is essential not only as a delicious fruit that is commonly consumed fresh for dessert but it may also be used in cosmetics since its extract contains antioxidant and moisturizing properties, as well as little to no side effects and a strong safety profile [41]. Because its fruit, seed, and bark contain unique chemical constituents, humans utilized this plant 
Table 2: Chemical contents isolated from Lansium domesticum Corr.

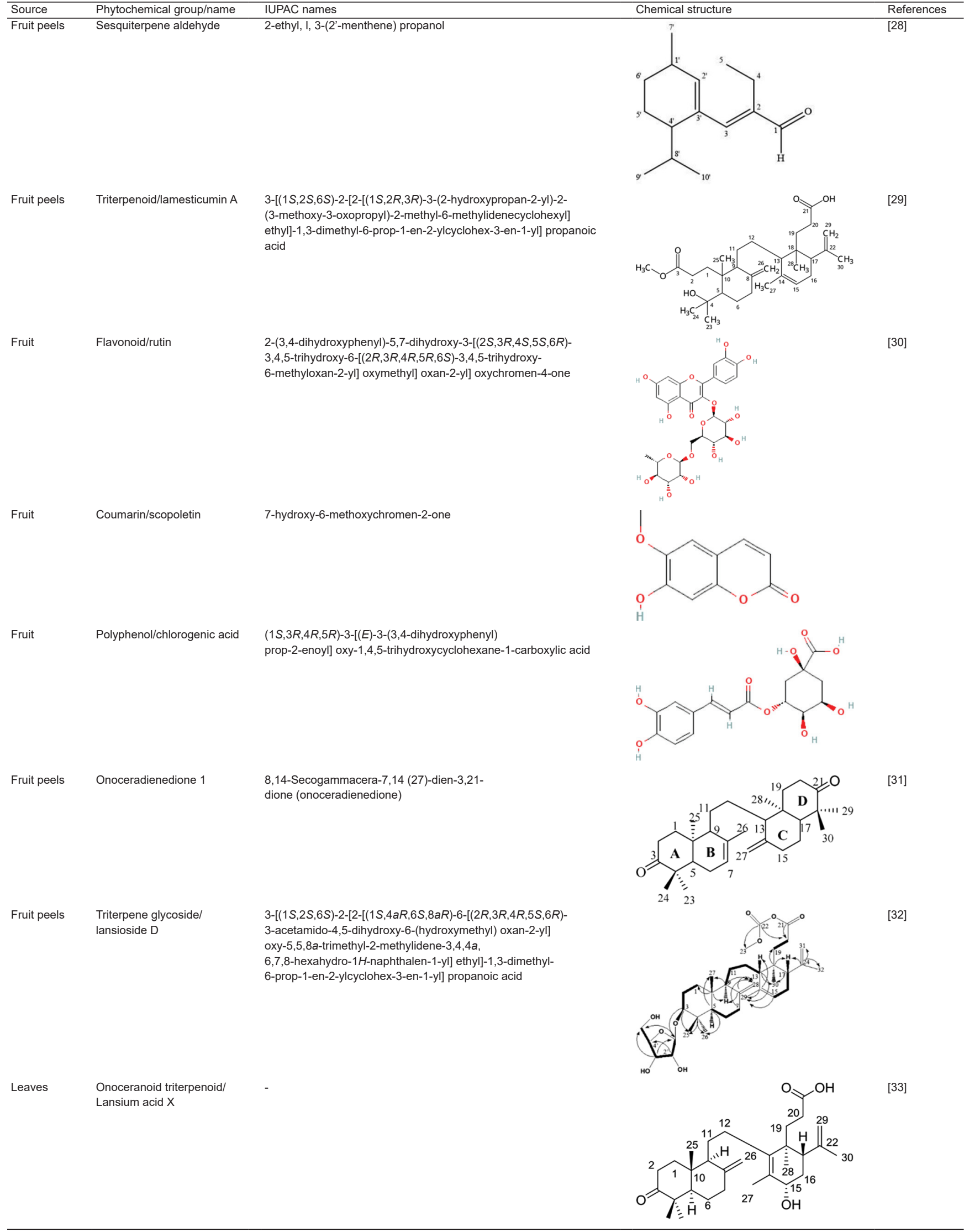

(Contd...) 


\section{Table 2: (Continued)}

\begin{tabular}{|c|c|c|c|c|}
\hline Source & Phytochemical group/name & IUPAC names & Chemical structure & References \\
\hline Leaves & $\begin{array}{l}\text { Onoceranoid triterpenoid/ } \\
\text { Lansium acid XI }\end{array}$ & - & & [33] \\
\hline Leaves & $\begin{array}{l}\text { Onoceranoid triterpenoid/ } \\
\text { Lansium acid XII }\end{array}$ & - & & [33] \\
\hline Leaves & $\begin{array}{l}\text { Onoceranoid triterpenoid/ } \\
\text { Lansium acid XIII }\end{array}$ & - & & [33] \\
\hline Seed & $\begin{array}{l}\text { Tetranortriterpenoids/ } \\
\text { Langsatides A }\end{array}$ & - & & [34] \\
\hline Seed & $\begin{array}{l}\text { Tetranortriterpenoids/ } \\
\text { Langsatides A }\end{array}$ & - & & [34] \\
\hline Leaves & Cardiac glycoside/Honghelin & - & & [35] \\
\hline Seed & Onoceranoid triterpenes & 3-hydroxy-8,14-secogammacera-7,14-dien-21-one & & [36] \\
\hline Fruit & $\begin{array}{l}\text { Onoceranoid triterpenes/ } \\
\text { methyl lansioside C }\end{array}$ & - & & [37] \\
\hline
\end{tabular}


Table 2: (Continued)

\begin{tabular}{lllll}
\hline Source & Phytochemical group/name & IUPAC names & Chemical structure \\
\hline Fruit peels & $\begin{array}{l}\text { Onoceranoid triterpenes/ } \\
\text { Lamesticumin } \mathrm{G}\end{array}$ & - & References \\
\hline
\end{tabular}

to cure digestive disorders and malaria [42]. Now, the activities of this plant have been more explored. Some of the activity reports will be explained in this article.

\section{Antioxidant activity}

Antioxidants are required by the body because they limit the beginning and progression of substrate oxidation. Beta-hydroxy acid, tert-butyl hydroquinone, propyl gallate, and butylated hydroxytoluene are examples of synthetic antioxidants that have been widely employed across the world [43], [44]. However, these synthetic antioxidants have negative side effects on the heart and lungs, including carcinogenic and cytotoxic consequences [45]. Natural items having antioxidant capabilities, such as $L$. domesticum, have been discovered (Table 3).

Using the 2,2-diphenyl-1-picrylhydrazyl (DPPH) technique, the antiradical potential of $L$. domesticum seeds extract and fractions was evaluated. In comparison to the n-hexane fraction, water fraction, and methanol extract, the ethyl acetate fraction provided a significant contribution as an antioxidant, with $\mathrm{IC}_{50}$ values of $8.938 \pm 0.031,11.012 \pm 0.094,13.898 \pm$ 0.81 , and $14.624 \pm 0.456 \mu \mathrm{g} / \mathrm{mL}$, respectively [42]
The negative consequences of $\mathrm{NO}$ overexpression in the host organism have traditionally been linked to a variety of illnesses, including human vascular and cardiac ailments. Two undescribed compounds from L. domesticum leaves extract, 17(20)E-dyscusin B and 17(20)Z-dyscusin B, demonstrated strong NO inhibition with $\mathrm{IC}_{50}$ values of 9.13 and $14.03 \mu \mathrm{M}$, respectively [46].

L. domesticum Corr. leaves were extracted using three distinct solvents: Water, chloroform, and methanol, in both hot and cold procedures. Antioxidant activity (DPPH radical scavenging and lipid peroxidation inhibition) was assessed in the crude extracts. The hot process methanol crude extract had the best DPPH radical scavenging activity $\left(\mathrm{SC}_{50}\right.$ values of $8.72 \pm$ $0.54 \mathrm{mg} / \mathrm{ml}$ ) while the water crude extract obtained by the hot process gave the best activity as lipid peroxidation inhibitor (IPC50 values of $3.29 \pm 0.30 \mathrm{mg} / \mathrm{ml}$ ) [47].

L. domesticum shows good potential as an antioxidant based on the report. In vitro chemical or cell culture tests are routinely employed to determine antioxidant activity. Animal bioassays are also becoming increasingly popular as a way to more precisely identify the effects of these chemicals on organ function and development, as well as in clinical trials. However, scientists are working to develop new, simpler, and

Table 3: Antioxidant activity of Lansium domesticum Corr.

\begin{tabular}{|c|c|c|c|c|}
\hline No. & Sample & Method & Result & References \\
\hline 1 & $\begin{array}{l}\text { Lansium domesticum seeds extract } \\
\text { and fractions } \\
\text { - Methanol extract } \\
\text { - Water fraction } \\
\text { - Ethyl acetate fraction } \\
\text { - n-Hexane fraction }\end{array}$ & DPPH assay & $\begin{array}{l}\mathrm{IC}_{50}(\mu \mathrm{g} / \mathrm{mL}) \text { values: } \\
\quad \cdot 14.6 \pm 0.4 \\
\cdot 13.8 \pm 0.8 \\
\cdot 8.9 \pm 0.03 \\
\cdot 11.0 \pm 0.09\end{array}$ & {$[42]$} \\
\hline 2 & $\begin{array}{l}\text { Two undescribed compounds from } \\
\text { Lansium domesticum leaves extract } \\
\text { • } 17 \text { (20) E-dyscusin B } \\
\text { •17 (20) Z-dyscusin B }\end{array}$ & Nitric oxide inhibition & $\begin{array}{l}\mathrm{IC}_{50}(\mu \mathrm{M}) \text { values: } \\
\quad \cdot 9.13 \\
\quad \cdot 14.03\end{array}$ & [46] \\
\hline 3 & $\begin{array}{l}\text { The fraction of Lansium domesticum } \\
\text { peel fruit extract ethanol }(\mathrm{mg} / \mathrm{mL}) \\
\text { - Dichloromethane fraction }(2.0) \\
\text { - Ethyl acetate fraction }(2.0) \\
\text { - Water fraction }(2.0)\end{array}$ & Hydroxyl radical scavenging activity & $\begin{array}{l}\% \text { inhibition degradation: } \\
\cdot 43.94 \pm 1.03 \\
\cdot 42.70 \pm 0.86 \\
\cdot 93.44 \pm 0.84\end{array}$ & [30] \\
\hline 4 & $\begin{array}{l}\text { Lansium domesticum leaves extract } \\
\text { - Water extract } \\
\text { - Methanol extract } \\
\text { - Chloroform extract }\end{array}$ & $\begin{array}{l}\text { DPPH radical scavenging assay } \\
\text { and } \\
\text { lipid Peroxidation inhibition }\end{array}$ & $\begin{array}{l}\text { Scavenging concentration at } 50 \% \text { activity } \\
(\mathrm{mg} / \mathrm{mL}) \text { : } \\
\cdot 5.40 \pm 1.23 \\
\cdot 8.72 \pm 0.54 \\
\cdot 6.15 \pm 0.78 \\
\text { Inhibition peroxidation concentration at } 50 \% \\
\text { activity }(\mathrm{mg} / \mathrm{mL}) \\
\cdot 3.29 \pm 0.30 \\
\cdot 4.61 \pm 0.65 \\
\cdot 18.77 \pm 1.78\end{array}$ & [47] \\
\hline
\end{tabular}


perhaps faster approaches that might supplement or replace established assays, notably for quality assurance screening of traditional medicine products. Various types of methods have been used to identify the antioxidant activity of $L$. domesticum Corr.

\section{Antibacterial activity}

Antibiotics were discovered, developed, and used clinically in the $19^{\text {th }}$ century, greatly reducing the public health risks associated with bacterial infections. The growth of bacterial resistance to current chemotherapeutic drugs as a result of their injudicious usage, on the other hand, is concerning. To overcome this problem, antibacterial research from medicinal plants was developed. Many medicinal plants have been used as traditional remedies to cure illnesses of pathogenic origin in humans all across the world. Plant extracts contain a variety of bioactive chemicals such as polyphenols, terpenes, and phytosterols, which operate in a variety of ways to inhibit or kill bacteria. This article will explain the activity of $L$. domesticum Corr. as an antibacterial based on research results.

The aqueous seeds extract of $L$. domesticum Corr. was showed antibacterial activity. As test organisms, Escherichia coli and Staphylococcus aureus, two harmful bacteria, were employed [48]. Antibacterial activity of an ointment containing L. domesticum seed extract was also reported. Ointment with a concentration of $10 \%$ L. domesticum seed extract showed inhibition against $S$. aureus [49]. On S. aureus and Klebsiella pneumoniae bacteria, inhibition of the $n$-hexane extract of $L$. domesticum fruit seeds exhibited the highest clear zone diameter value supplied by the lowest concentration of $10 \%$ using the disc and well technique [50].

These findings indicate that the extract has either strong antibacterial efficacy or a high concentration of an active component. The findings show that $L$. domesticum can be used in traditional medicine to treat diseased skin. As a result, when the widths of the inhibition zones and the MIC are taken into account, the wound healing activity of this plant appears to be the most intriguing for further research.
In addition, the action of this plant as an antibacterial is an interesting thing to research and report on.

\section{Cytotoxic activity}

Uncontrolled cell proliferation and differentiation are hallmarks of cancer. It has the ability to infect organs and tissues, and it is a serious public health concern in both developed and developing countries [45]. The assessment of cytotoxic activity against cancer cell lines in vitro and animal cancer models in vivo was a major factor in the development of new anticancer drugs from natural sources such as plants, marine creatures, and microorganisms [51]. Plants have been used to cure cancer for 1000 of years. Vinblastine and vincristine, obtained from the Madagascar periwinkle, Catharanthus roseus G. Don. (Apocynaceae), and paclitaxel, isolated from the bark of Taxus brevifolia Nutt. (Taxaceae), are among the more than 3000 plant species that have been reported for cancer therapy [52], [53]. This study reports on the potential of $L$. domesticum Corr. as an anticancer based on research that has been found (Table 4).

Cytotoxic activity shows the potential of a material as an anticancer agent. Based on the data in Table 4, L. domesticum Corr. has cytotoxic activity on several types of cancer cells such as liver cancer cells (HepG2), colon cancer cells (WidR and HT-29), breast cancer cells (T47D), oral cancer cells (KB), and melanoma cancer cells (B16F10). Cytotoxic activity was obtained from various types of plant parts such as seeds, fruits, fruit peels, and leaves. Not only that, secondary metabolites that have been isolated have also shown cytotoxic activity on cancer cells, namely, sesquiterpene aldehydes.

L. domesticum Corr. is reported to contain a lot of secondary metabolites of the steroid/terpenoid group. Terpenoids are chemical molecules that are made up of five carbon units (isoprene) that have been built and changed in various ways [59]. Terpenoids are a group of essential secondary metabolites in plants that have a variety of forms. They are the most numerous molecules in natural goods including in this plant. With their specific structural properties and strong anticancer activity, terpenoids have piqued the interest of many

Table 4: Cytotoxic activity of Lansium domesticum Corr.

\begin{tabular}{|c|c|c|c|}
\hline Sample & Method & Results & References \\
\hline Chloroform extract of young fruit & In vitro in $\mathrm{KB}, \mathrm{HT}-29, \mathrm{HepG}$, and $\mathrm{B} 16 \mathrm{~F} 10$ cell lines & $\begin{array}{l}\mathrm{IC}_{50}(\mu \mathrm{g} / \mathrm{mL}) \text { value was determined by SRB assay } \\
983.81 \pm 13.17 \text { (KB cell), } 934.89 \pm 52.43 \text { (HT-28 cell), } 934.00 \pm \\
46.20 \text { (HepG2 cell), and } 421.5 \pm 12.98 \text { (B16F10 cell) }\end{array}$ & [54] \\
\hline Ethyl acetate extract of peel fruit & In vitro in T47D cells line & The $\mathrm{IC}_{50}$ is $29.41 \pm 0.67 \mu \mathrm{g} / \mathrm{mL}$ & [29] \\
\hline Chloroform young fruit extract & In vitro in $\mathrm{KB}$ cells line & The $\mathrm{IC}_{50}$ values is $603.45 \pm 55.35 \mu \mathrm{g} / \mathrm{mL}$ & [55] \\
\hline $\begin{array}{l}\text { Kokosanolid A and C from Lansium } \\
\text { domesticum Corr. seed }\end{array}$ & $\begin{array}{l}\text { In silico test of molecular interactions of } \\
\text { kokosanolid } A \text { and kokosanolid } C \text { with the estrogen } \\
\text { receptor } \alpha(E R \alpha)\end{array}$ & $\begin{array}{l}\text { Kokosanolid } \mathrm{A} \text { and } \mathrm{C} \text { showed strong bond-free energy } \\
(-8.8 \mathrm{kcal} / \mathrm{mol} \text { and }-8.7 \mathrm{kcal} / \mathrm{mol}) \text { to } \mathrm{ER \alpha} \text {. } \\
\text { These two compounds have } \\
\text { molecular mechanism to inhibit ERa in breast cancer cells. }\end{array}$ & [56] \\
\hline $\begin{array}{l}\text { Methanol extract of Lansium } \\
\text { domesticum Corr. fruit }\end{array}$ & In vitro in $\mathrm{HT}-29$ cells line & $\begin{array}{l}\mathrm{IC}_{50} \text { value was determined by MTT assay after } 2 \text { days incubated } \\
(50.00 \pm 0.02 \mu \mathrm{g} / \mathrm{mL})\end{array}$ & [57] \\
\hline $\begin{array}{l}\text { Active compound of fruit peel extract } \\
\text { (sesquiterpene aldehyde) }\end{array}$ & In vitro in T47D and HepG2 cell lines & $\begin{array}{l}\mathrm{IC}_{50}(\mu \mathrm{g} / \mathrm{mL}) \text { value was determined by MTT assay } 48.58 \pm 0.96 \\
(\mathrm{~T} 47 \mathrm{D}) \text { and } 127.45 \pm 25.76(\mathrm{HepG})\end{array}$ & [28] \\
\hline $\begin{array}{l}\text { Active compound of fruit peel extract } \\
\text { (sesquiterpene aldehyde) }\end{array}$ & In vitro in WidR cells line & The $\mathrm{IC}_{50}$ is $>50 \mu \mathrm{g} / \mathrm{mL}$ & [58] \\
\hline
\end{tabular}


medicinal chemists, and they have the potential to be lead molecules in the development of effective and safe antitumor medicines [60], [61], [62].

\section{Conclusions}

L. domesticum Corr. is a fruit-producing plant known as duku and is found in Southeast Asia, one of which is Indonesia. This plant has been widely used by the community such as its fruit that can be consumed so that it is sold in the market to improve the economy. Some parts such as leaves, fruit, fruit skins, and seeds contain secondary metabolite compounds so they are used as folk remedies. Based on the data that have been collected, L. domesticum Corr. has good antioxidant activity properties, is efficacious as an antibacterial, and has the potential to be developed as an anticancer because it has cytotoxic properties. Further studies are needed to explore the activity of $L$. domesticum Corr. so that it can be developed as a standardized herbal.

\section{Acknowledgments}

The authors would like to say thank you for Universitas Sumatera Utara.

\section{References}

1. Taek MM, Ew BP, Agil M. Plants used in traditional medicine for treatment of malaria by Tetun ethnic people in West Timor Indonesia. Asian Pac J Trop Med. 2018;11(1):630-7. https://doi. org/10.4103/1995-7645.246339

2. Supiandi $M I$, Ege $B$, Julung $H$, Zubaidah $S$, Mahanal $S$. Ethnobotany of traditional medicine in Dayak Jangkang tribe, Sanggau district, West Kalimantan, Indonesia. Biodiversitas. 2021;22(12):5417-24. https://doi.org/10.13057/biodiv/d221224

3. Susanti R, Zuhud EA. Traditional ecological knowledge and biodiversity conservation: The medicinal plants of the Dayak Krayan people in Kayan Mentarang National Park, Indonesia. Biodiversitas. 2019;20(9):2764-79. https://doi.org/10.13057/ biodiv/d200943

4. Verma R, Gangrade T, Punasiya R, Ghulaxe C. Rubus fruticosus (blackberry) use as an herbal medicine. Pharmacogn Rev. 2014;8(16):101-4. https://doi.org/10.4103/0973-7847.134239 PMid:25125882

5. Rosidah Y, Widjaja SS, Auliafendri N, Lubis MF, Muhammad M, Satria D. Phytochemicals analysis and immunomodulatory activity of saurauia vulcani korth. leaves extracts towards raw 264.7 cell. Rasayan J Chem. 2021;14(2):1378-83. https://doi. org/10.31788/rjc.2021.1426075

6. Yulita KS. Genetic variations of Lansium domesticum Corr. accessions from Java, Sumatra and Ceram based on Random
Amplified Polymorphic DNA fingerprints. Biodivers J Biol Divers. 2011;12(3):125-30. https://doi.org/10.13057/biodiv/d120301

7. Darmadi D, Meilasri S. Secondary metabolite compounds of duku skin (Lansium domesticum corr) as an inhibitor of egg maturation of egg Ascaris lumbriccoides. Klin Sains J Anal Kesehat. 2019;7(2):68-75. https://doi.org/10.36341/klinikal_ sains.v7i2.1056

8. Subandrate $S$, Sinulingga $S$, Wahyuni $S$, Altiyan MF, Fatmawati F. Antioxidant potential of Lansium domesticum corr. seed extract in white male rat (Rattus novergicus) induced by alcohol. Molekul. 2016;11(1):1-8.

9. Shankar S, Jaiswal L, Aparna RS, Prasad RG. Synthesis, characterization, in vitro biocompatibility, and antimicrobial activity of gold, silver and gold silver alloy nanoparticles prepared from Lansium domesticum fruit peel extract. Mater Lett. 2014;137:75-8. https://doi.org/10.1016/j.matlet.2014.08.122

10. Nyoman I, Sjaifullah A, Cahyani DJ, Ayu WD. Onoceranoid triterpene from langsep leaf (Lansium domesticum Corr.) and its insecticide activity to Spodoptera littura. J ILMU DASAR. 2017;18(1):9-16.

11. Ni'mah $T$, Oktarina $R$, Mahdalena V, Asyati $D$. Potential of duku seed extract (Lansium domesticum Corr) against Aedes aegypti. Bul Penelit Kesehat. 2015;43(2):131-6. https://doi. org/10.22435/bpk.v43i2.4147.131-136

12. Hanum L, Negara ZP, Dahlan Z. Morphological diversity of Lansium domesticum Corr in South Sumatra. Sci Technol Indones. 2018;3(1):41-4. https://doi.org/10.26554/ sti.2018.3.1.41-44

13. Wong KC, Wong SW, Siew SS, Tie DY. Volatile constituents of the fruits of Lansium domesticum correa (Duku and Langsat) and Baccaurea motleyana (Muell. Arg.) Muell. Arg. (Rambai). Flavour Fragr J. 1994;9(6):319-24. https://doi.org/10.1002/ ff. 2730090608

14. Pontoh J, Kamu VS, Sitorus LP. Analysis of organic acid in langsat (Lansium domesticum var pubescens) and Duku (Lansium domesticum var. domesticum) fruits by reversed phase HPLC technique. Int J ChemTech Res. 2015;8(7):238-42.

15. Techavuthiporn C, Langsat Lansium domesticum. Amsterdam, Netherlands: Elsevier Inc.; 2018.

16. Huang WY, Cai YZ, Corke H, Sun M. Survey of antioxidant capacity and nutritional quality of selected edible and medicinal fruit plants in Hong Kong. J Food Compos Anal. 2010;23(6):510-7. https://doi.org/10.1016/j.jfca.2009.12.006

17. Hasibuan PA, Harahap U, Sitorus P, Lubis MF, Satria D. In-silico analysis of vernonioside $d$ and vernonioside e from vernonia amygdalina delile. Leaves as inhibitor of epidermal growth factor receptor (egfr) and mammalian target of rapamycin (mtor). Rasayan J Chem. 2021;14(3):1539-43. https://doi. org/10.31788/RJC.2021.1436092

18. Hasibuan PA, Munir D, Pertiwi D, Satria D, Lubis MF Flavonoids constituent analysis and cell cycle inhibition activity of ethylacetate extract of Vernonia amygdalina delile. Leaves on lung cancer cell line. Rasayan J Chem. 2020;13(4):2577-81. https://doi.org/10.31788/RJC.2020.1345625

19. Venugopala KN, Rashmi V, Odhav B. Review on natural coumarin lead compounds for their pharmacological activity. Biomed Res Int. 2013:2013:963248. https://doi.org/10.1155/2013/963248

20. Batiha GE, Beshbishy AM, Ikram M, Mulla ZS, Abd El-Hack ME, Taha $A E$, et al. The pharmacological activity, biochemical properties, and pharmacokinetics of the major natural polyphenolic flavonoid: Quercetin. Foods. 2020;9(3):374. https://doi.org/10.3390/foods9030374 PMid:32210182

21. Rios JL, Simeon S, Villar A. Pharmacological activity of aporphinoid alkaloids. A review. Fitoterapia. 1989;60(5):387412. https://doi.org/10.63019/ajb.v1i2.467 
22. Sallam IE, Abdelwareth A, Attia H, Aziz RK, Homsi MN, von Bergen $\mathrm{M}$, et al. Effect of gut microbiota biotransformation on dietary tannins and human health implications. Microorganisms. 2021;9(5):965. https://doi.org/10.3390/microorganisms9050965 PMid:33947064

23. Biswas D, Nazir R, Biswas P, Kumar V, Nandy S, Mukherjee A, et al. Endophytic sources of diosgenin, a natural steroid with multiple therapeutic values. S Afr J Bot. 2020;134:119-25 https://doi.org/10.1016/j.sajb.2020.04.009

24. Qurrohman T, Basyuni M, Hasibuan PA. Polyisoprenoids from avicennia marina induces on p13k, akt1, mammalian target of rapamycin, egfr, and p53 gene expression using reverse transcription-polymerase chain reaction. Open Access Maced J Med Sci. 2020;8(A):146-52. https://doi.org/10.3889/ oamjms.2020.3328

25. Celik S, Ozkok F, Ozel AE, Sahin YM, Akyuz S, Sigirci BD, et al. Synthesis, FT-IR and NMR characterization, antimicrobial activity, cytotoxicity and DNA docking analysis of a new anthraquinone derivate compound. J Biomol Struct Dyn. 2020;38(3):756-70. https://doi.org/10.1080/07391102.2019.158 7513

\section{PMid:30890106}

26. Hasibuan PA, Harahap U, Sitorus P, Satria D. The anticancer activities of Vernonia amygdalina Delile. Leaves on 4T1 breast cancer cells through phosphoinositide 3-kinase (PI3K) pathway. Heliyon. 2020;6(7):e04449. https://doi.org/10.1016/j. heliyon.2020.e04449

27. Sukatendel K, Siregar MF, Natadisastra M, Nasution IP, Ilyas S, Tala MR, et al. Benefits of Nigella sativa extract protecting ovary due to cisplatin chemotherapy. Open Access Maced J Med Sci. 2021;9(A):680-7. https://doi.org/10.3889/oamjms.2021.6446

28. Fadhilah K, Wahyuono S, Astuti P. Fractions and isolated compounds from Lansium domesticum fruit peel exhibited cytotoxic activity against $t-47 \mathrm{~d}$ and hepg 2 cell lines. Biodiversitas. 2021;22(9):3743-8. https://doi.org/10.13057/biodiv/d220918

29. Wahyuono S, Fadhilah K, Astuti P. A bioactive compound isolated from Duku (Lansium domesticum Corr) fruit peels exhibits cytotoxicity against T47D cell line. F1000Research. 2021;9:3. https://doi.org/10.12688/f1000research.21072.2 PMid:34136135

30. Klungsupya $P$, Suthepakul N, Muangman T, Rerk-Am U, Thongdon-A J. Determination of free radical scavenging, antioxidative DNA damage activities and phytochemical components of active fractions from Lansium domesticum corr. Fruit. Nutrients. 2015;7(8):6852-73. https://doi.org/10.3390/ nu7085312.

PMid:26287238

31. Labibah Q, Tun KN, Aminah NS, Kristanti AN, Ramadhan R, Takaya Y, et al. Cytotoxic constituent in the fruit peel of Lansium domesticum. Rasayan J Chem. 2021;14(2):1336-40. https://doi. org/10.31788/RJC.2021.1426044

32. Marfori FK, Kajiyana SI, Fukusaki EI, Kobayashi A. Lansioside antibiotic from the fruit peel of Lansium domesticum correa. J Pharmacogn Phytochem. 2015;3(5):140-3.

33. Matsumoto T, Kitagawa T, Ohta T, Yoshida T, Imahori D, Teo S, et al. Structures of triterpenoids from the leaves of Lansium domesticum. J Nat Med. 2019;73(4):727-34. https://doi. org/10.1007/s11418-019-01319-2 PMid:31104253

34. Rudiyansyah, Alimuddin AH, Masriani, Muharini R, Proksch P. New tetranortriterpenoids, langsatides $A$ and $B$ from the seeds of Lansium domesticum Corr. (Meliaceae). Phytochem Lett. 2018;23:90-3. https://doi.org/10.1016/j.phytol.2017.11.019

35. Tsuchiya A, Makita $Y$, Koyano $T$, Kowithayakorn $T$, Ishibashi M, Arai MA. Isolation and evaluation of cardenolides from Lansium domesticum as Notch inhibitors. J Nat Med. 2020;74(4):758-66. https://doi.org/10.1007/s11418-020-01432-7

PMid:32648094

36. Zulfikar, Putri NK, Fajriah S, Yusuf M, Maharani R, Al Anshori J, et al. 3-hydroxy-8,14-secogammacera-7,14-dien-21-one: A new onoceranoid triterpenes from Lansium domesticum corr. cV kokossan. Molbank. 2020;4:1-5. https://doi.org/10.3390/M1157

37. Ramadhan R, Worawalai W, Phuwapraisirisan P. New onoceranoid xyloside from Lansium parasiticum. Nat Prod Res. 2019;33(20):2917-24. https://doi.org/10.1080/14786419.2018.1 510395

PMid:30392392

38. Potipiranun $T$, Worawalai $\mathrm{W}$, Phuwapraisirisan $\mathrm{P}$ Lamesticumin $G$, a new $\alpha$-glucosidase inhibitor from the fruit peels of Lansium parasiticum. Nat Prod Res. 2018;32(16):18816. https://doi.org/10.1080/14786419.2017.1354184

39. Fidiana DF, Nurullita U. Power kill the skin extract Duku (Lansium domesticum Corr) on death larva Aedes aegypti. J Kesehat Masy Indones. 2013;8(2):22-9.

40. Octaviana D, Nurlaela S, Anandari D, Pradani FY. Lansium domesticum Corr. leaf extract spray as bioinsecticide for Aedes aegypti mosquito control. Int J Public Health Clin Sci. 2020;7(2):51-9.

41. Lukitaningsih $E$, Saputro $A H$, Widiasri $M$, Khairunnisa $N$ Prabaswari N, Kuswahyuningsih R. In vitro antiaging analysis of topical pharmaceutical preparation containing mixture of strawberry fruit, pomelo peel, and langsat fruit extracts. Indones J Chemom Pharm Anal. 2020;1(1):53. https://doi.org/10.22146/ ijcpa.603

42. Yamin $Y$, Ruslin $R$, Sabarudin $S$, Sida NA, Kasmawati $H$, Diman LO. Determination of antiradical activity, total phenolic, and total flavonoid contents of extracts and fractions of langsat (Lansium domesticum Coor.) Seeds. Borneo J Pharm. 2020;3(4):249-56. https://doi.org/10.33084/bjop.v3i4.1500

43. Tonolo F, Fiorese F, Moretto L, Folda A, Scalcon V, Grinzato A, et al. Identification of new peptides from fermented milk showing antioxidant properties: Mechanism of action. Antioxidants. 2020;9(2):117. https://doi.org/10.3390/antiox9020117 PMid:32013158

44. Yan Z, Zhong Y, Duan Y, Chen Q, Li F. Antioxidant mechanism of tea polyphenols and its impact on health benefits. Anim Nutr. 2020;6(2):115-23. https://doi.org/10.1016/j.aninu.2020.01.001 PMid:32542190

45. Baschieri A, Amorati R. Methods to determine chain-breaking antioxidant activity of nanomaterials beyond dpph: A review. Antioxidants. 2021;10(10):1-21. https://doi.org/10.3390/ antiox10101551

46. Ji KL, Dai MY, Xiao CF, Xu YK. Two new steroids with NO inhibitory effects from Lansium domesticum. Nat Prod Res. 2021;35(7):1147-52. https://doi.org/10.1080/14786419.2019.16 43862

\section{PMid:31315445}

47. Manosroi A, Kumguan K, Chankhampan C, Manosroi W, Manosroi J. Nanoscale gelatinase A (MMP-2) inhibition on human skin fibroblasts of longkong (Lansium domesticum Correa) leaf extracts for anti-aging. J Nanosci Nanotechnol. 2012;12(9):7187-97. https://doi.org/10.1166/jnn.2012.6500 PMid:23035451

48. Alfonso ED, Fernando SI, Pineda PS, Divina CC. Antibacterial activity and genotoxicity assays of lanzones (Lansium domesticum) seeds extract. Int J Agric Technol. 2017;13(7-3):2427-34

49. Umair TP, Wijaya F, Ernanto JH, Parulian T. The effect of Lansium domesticum Corr duku extract on wound healing. 2020;8-11.

50. Nurhamidin AP, Antasionasti I. Antibacterial activity test of 
n-hexane extract of langsat fruit SEEDS (Lansium domesticum Corr) against Staphylococus aureus and Klebsiella pneumoniae bacteria uji aktivitas antibakteri ekstrak n-heksan biji buah langsat (Lansium domesticum Corr) TER. 2021;10:32772. https://doi.org/10.35799/pha.10.2021.32772

51. Abotaleb M, Liskova A, Kubatka P. Therapeutic potential of plant phenolic acids in the treatment of cancer. Biomolecules 2020;10:221. https://doi.org/10.3390/biom10020221

PMid:32028623

52. Mazalovska M, Kouokam JC. Review article plant-derived lectins as potential cancer therapeutics and diagnostic tools. Biomed Res Int. 2020;2020:1631394. https://doi. org/10.1155/2020/1631394

53. Kiskova T, Kubatka P, Büsselberg D. The plant-derived compound resveratrol in brain cancer: A review. Biomolecules. 2020;10(1):161. https://doi.org/10.3390/biom10010161 PMid:31963897

54. Manosroi A, Jantrawut P, Sainakham M, Manosroi W, Manosroi J. Anticancer activities of the extract from Longkong (Lansium domesticum) young fruits. Pharm Biol. 2012;50(11):1397-407. https://doi.org/10.3109/13880209.2012.682116 PMid:22849519

55. Manosroi A, Chankhampan C, Manosroi W, Manosroi J. Anti-proliferative and matrix metalloproteinase-2 inhibition of Longkong (Lansium domesticum) extracts on human mouth epidermal carcinoma. Pharm Biol. 2013;51(10):1311-20. https:// doi.org/10.3109/13880209.2013.790064

\section{PMid:23763335}

56. Purwani S, Nahar J, Zulfikar Z, Nurlelasari N, Mayanti T. Molecular docking on kokosanolide $\mathrm{A}$ and $\mathrm{C}$ for anticancer activity against human breast cancer cell MCF-7. J Kim Val. 2021;7(1):52-7. https://doi.org/10.15408/jkv.v7i1.20534

57. Khalili RM, et al. Cytotoxicity effect and morphological study of different duku (Lansium domesticum corr.) extract towards human colorectal adenocarcinoma cells line (HT-29). Pharmacogn J. 2014;9(6):757-61. https://doi.org/10.5530/pj.2017.6.119

58. Fadhilah K, Wahyuono S, Astuti P. A sesquiterpene aldehyde isolated from ethyl acetate extract of Lansium domesticum fruit peel. Indones J Pharm. 2021;32(3):394-8. https://doi. org/10.22146/ijp.1884

59. Bello OA, Ayanda OI, Aworunse OS, Olukanmi BI. Can medicinal properties of watercress be relevant to human health? A systematic review based on preclinical study in vivo. Pharmacogn Rev. 2018;1(2):8-15. https://doi.org/10.4103/ phrev.phrev

60. Yang W, Chen X, Li Y, Guo S, Wang Z, Yu X. Advances in pharmacological activities of terpenoids. Nat Prod Commun. 2020;15(3):355. https://doi.org/10.1177/1934578X20903555

61. Thoppil RJ, BishayeeA. Terpenoids as potential chemopreventive and therapeutic agents in liver cancer. World $\mathrm{J}$ Hepatol. 2011;3(9):228-49. https://doi.org/10.4254/wjh.v3.i9.228 PMid:21969877

62. Bergman ME, Davis B, Phillips MA. Occurrence, and mechanism of action. Molecules: 2019;24(21):1-23. 